\title{
Novel links between ciliopathies and FGF-related craniofacial syndromes
}

\author{
K Liu $^{1 *}$, JT Tabler ${ }^{1}$, HL Szabo-Rogers ${ }^{1}$, A Mesbahi ${ }^{1}$, C Healy ${ }^{1}$, W Barrell ${ }^{1}$, B Wlodarczyk ${ }^{2}$, JB Wallingford ${ }^{3}$, R Finnell ${ }^{3}$ \\ From First International Cilia in Development and Disease Scientific Conference (2012) \\ London, UK. 16-18 May 2012
}

Recent studies suggest that planar cell polarity (PCP) genes coordinate cell polarity, ciliogenesis and signalling during mammalian development. FUZ is a PCP gene implicated in human congenital anomalies, including neural tube defects and orofacial clefting. Our analysis of fuzzy mutant mice reveals ciliogenesis defects in craniofacial tissues as well as a suite of phenotypes reminiscent of FGF-related craniofacial disorders. Mutants have coronal synostosis, shortened facial extensions, low-set ears and a high-arched palate. To our surprise, we found that the facial defects are due to increased neural crest migration into the first branchial arch (BA1), resulting in maxillary hyperplasia. Furthermore, the neural crest cells migrate in a disorganized fashion, deeper than normal and with fewer cell-cell contacts. This ectopic migration correlates with a dramatic increase in FGF signaling, first in the midhindbrain boundary, and then in the BA1 epithelia. The increased tissue causes a medial positional shift in the palatal primordia that manifests as a high-arched palate with pseudo-cleft. Genetic loss of $f g f 8$ rescues the maxillary hyperplasia. Taken together, our data suggest a novel interplay between ciliogenesis, FGF signalling and migration of neural crest which may underlie congenital craniofacial dysmorphologies.

\section{Author details}

${ }^{1}$ King's College London, UK. ${ }^{2}$ University of Texas Southwestern, USA.

${ }^{3}$ University of Texas at Austin, USA.

Published: 16 November 2012

doi:10.1186/2046-2530-1-S1-O25
Cite this article as: Liu et al.: Novel links between ciliopathies and FGF-
related craniofacial syndromes. Cilia 2012 1(Suppl 1):O25.

* Correspondence: karen.liu@kcl.ac.uk

${ }^{1}$ King's College London, UK

Full list of author information is available at the end of the article
Submit your next manuscript to BioMed Central and take full advantage of:

- Convenient online submission

- Thorough peer review

- No space constraints or color figure charges

- Immediate publication on acceptance

- Inclusion in PubMed, CAS, Scopus and Google Scholar

- Research which is freely available for redistribution
C Biomed Central
C Biomed Central

C 2012 Liu et al; licensee BioMed Central Ltd. This is an Open Access article distributed under the terms of the Creative Commons Attribution License (http://creativecommons.org/licenses/by/2.0), which permits unrestricted use, distribution, and reproduction in any medium, provided the original work is properly cited. 